\title{
Effects of Delayed Finishing/Polishing on Surface Roughness, Hardness and Gloss of Tooth-Coloured Restorative Materials
}

\author{
A. Ruya Yazicia \\ Duygu Tuncerb \\ Sibel Antonson \\ Alev Onen ${ }^{\mathrm{d}}$ \\ Evren Kilinc ${ }^{e}$
}

\section{ABSTRACT}

Objectives: The aim of this study was to investigate the effect of delayed finishing/polishing on the surface roughness, hardness and gloss of tooth-coloured restorative materials.

Methods: Four different tooth-coloured restoratives: a flowable resin composite- Tetric Flow, a hybrid resin composite- Venus, a nanohybrid resin composite- Grandio, and a polyacid modified resin composite- Dyract Extra were used. 30 specimens were made for each material and randomly assigned into three groups. The first group was finished/polished immediately and the second group was finished/polished after 24 hours. The remaining 10 specimens served as control. The surface roughness of each sample was recorded using a laser profilometer. Gloss measurements were performed using a small-area glossmeter. Vickers microhardness measurements were performed from three locations on each specimen surface under $100 \mathrm{~g}$ load and $10 \mathrm{~s}$ dwell time. Data for surface roughness and hardness were analyzed by Kruskal Wallis test and data for gloss were subjected to one-way ANOVA and Tukey test $(P<.05)$.

Results: The smoothest surfaces were obtained under Mylar strip for all materials. While there were no significant differences in surface roughness of immediate and delayed finished/polished Dyract Extra samples, immediately finished/polished Venus and Grandio samples showed significantly higher roughness than the delayed polished samples ( $\mathrm{P}<.05)$. In Tetric Flow samples, immediately finishing/polishing provided smoother surface than delayed finishing/polishing $(\mathrm{P}<.05)$. The highest gloss values were recorded under Mylar strip for all materials. While delayed finishing/polishing resulted in a significantly higher gloss compared to immediate finishing/polishing in Venus samples $(P<.05)$, no differences were observed between delayed or immediate finishing/polishing for the other materials ( $P>$.05). The lowest hardness values were found under Mylar strip. Delayed finishing/polishing significantly increased the hardness of all materials.

Conclusions: The effect of delayed finishing/polishing on surface roughness, gloss and hardness appears to be material dependent. (Eur J Dent 2010;4:50-56)

Key words: Hardness; Roughness; Gloss; Tooth-coloured restorative materials; Finishing; Polishing.

associate Professor, Hacettepe University, Faculty of Dentistry, Department of Conservative Dentistry, Ankara, Turkey.

${ }^{b}$ Research assistant, Hacettepe University, Faculty of Dentistry, Department of Conservative Dentistry, Ankara, Turkey.

Associate Professor, SUNY University, School of Dental Medicine, Department of Restorative Dentistry, Buffalo, NY, USA.

d Professor, Hacettepe University, Faculty of Dentistry, Department of Conservative Dentistry, Ankara, Turkey.
Instructor, Nova Southeastern Collage of Dentistry, Department of Restorative Dentistry, Fort Lauderdale, FL, USA.

- Corresponding author:

\section{A. Ruya Yazici}

Hacettepe University, Faculty of Dentistry,

Dept. of Conservative Dentistry,

06100, Sihhiye, Ankara, Turkey

Fax: +90 3123104440

E-mail: ruyaylahacettepe.edu.tr 


\section{INTRODUCTION}

The smoothness of restorative material's surfaces has a great importance in the success and clinical longevity of the restorations. ${ }^{1-3}$ It is known that materials with rough surfaces enhance bacterial adhesion and decrease stain resistance. ${ }^{4-6}$ Especially restorations in close contact to gingival tissues require surface smoothness for optimal gingival health as well. ${ }^{7}$ Surface gloss is another factor playing an important role on the appearance of tooth-coloured restorative resins. ${ }^{8}$ Gloss is a desirable characteristic for restorative materials to mimic the appearance of the enamel. ${ }^{9,10} \mathrm{~A}$ smooth and glossy surface is generally obtained under a Mylar strip without subsequent finishing or polishing, but unfortunately intra-oral finishing is always required. ${ }^{11}$ Moreover, such a surface has a higher resin content and will reduce the wear resistance of the restoration over time. Therefore, finishing and polishing of tooth-coloured restorative materials after placement are inevitable procedures that will improve esthetics, early wear resistance, color stability and marginal integrity. ${ }^{1,2,5}$

Hardness that might be defined as the resistance of a material to indentation is an important mechanical property that predicts the degree of cure of restorative materials. ${ }^{12,13}$ Hardness has also been used to predict the wear resistance of a material and its ability to abrade or be abraded by opposing dental structures or materials. ${ }^{14}$ Restorations that are not properly polymerized may result with a softer surface that will retain the scratches created by the finishing procedures. These scratches can compromise the fatigue strength of the restoration and lead to premature failures. ${ }^{15}$

Proper finishing and polishing should establish a smooth, glossy surface texture with optimum restoration contour facilitating the removal of plaque. ${ }^{16-18}$ The timing of the finishing/polishing procedure might have an effect on the physical properties of the restorative materials, and might increase the risk of premature failures. Although several authors have proposed a 24-hour delay before the completion of finishing procedures, ${ }^{19,20}$ most clinicians perform finishing/polishing procedures immediately after restoration placement.

The effect of different finishing/polishing systems on surface hardness and roughness of com- posite resins has been widely reported in the literature. ${ }^{21-23}$ However, the effect of delaying finishing/ polishing procedures is less investigated.

The aim of this study was to investigate the effect of delayed finishing/polishing on the surface hardness, roughness and gloss of different groups of tooth-coloured restorative materials.

\section{MATERIALS AND METHODS}

Four different tooth-coloured restorative materials were used in the study: a flowable resin composite- Tetric Flow (Ivoclar Vivadent AG, Schaan, Liechtenstein); a hybrid resin composite- Venus (Heraus Kulzer, Dormagen, Germany); a nanohybrid resin composite- Grandio (Voco, Cuxhaven, Germanyl and a polyacid modified resin composite- Dyract Extra (Dentsply Caulk, Milford, DE, USA) (Table 1). All materials were of A2 shades. A teflon mold (10-mm in diameter and 2-mm thick) was used to prepare 30 specimens from each of the restorative materials. To prepare each specimen, the mold was placed on a Mylar strip covered glass slide and the uncured resin composites were placed in the molds. Another Mylar strip was then placed over the mold and the material was compressed with a glass slide, thus extruding the excess resin composite and forming a flat surface. The samples were polymerized from the top of the mold with a tungsten halogen light (Hilux, Benlioglu, Ankara, Turkeyl according to the manufacturer's recommended polymerization times. The intensity of the curing light was $550 \mathrm{~mW} / \mathrm{cm}^{2}$, as verified with a hand-held radiometer (Curing Radiometer Model 100, Demetron/Kerr, Danbury, CT, USA). A control group of 10 specimens of each material received no finishing and polishing procedures after being cured under Mylar strip. The remaining 20 specimens from each restorative material were randomly divided into two groups ( $n=10 /$ group) according to the finishing/polishing time. Ten specimens from each restorative material were finished and polished immediately after the polymerization; the other 10 were finished and polished 24 hours later.

Finishing was performed with $30 \mu \mathrm{m}$ diamond finishing burs (Diatech, Diatech Dental AC, Heerbrugg, Switzerland) with a high-speed hand-piece at 40,000 rpm under three-way water-cooling. The application time was limited to 10 seconds. A new finishing bur was used for every five samples. 
Medium to super-fine aluminum oxide discs (Sof-Lex, 3M, St. Paul, MN, USA) were used for polishing. The aluminum oxide discs were discarded after each use. Each disc was used in a circular motion with light pressure for 20 seconds with a slow-speed hand piece (NSK Ti-Max Electric Handpiece, Japan). The rpm was set to 5,000. To control the variability, one investigator, blinded to which material was being processed, performed all the finishing and polishing procedures in a randomized order. All groups were stored in saline for two weeks at $37^{\circ} \mathrm{C}$ before analyses. ${ }^{24,25}$

\section{Measurement of surface roughness}

The surface roughness of each specimen was recorded using a laser profilometer (MicroXAM Interferometric Surface Profiler, Dublin, Ireland) by a second operator who was also blind to the restorative materials and finishing/polishing procedures.

The average surface roughness ( $\mathrm{Ra}, \mu \mathrm{m})$ was measured using MapVue AE software, Version 1.20. Three tracings at different locations on eachspecimen were recorded. Profilometer results were analyzed taking the Ra value into consideration.

Table 1. Restorative materials and compositions (Bis-GMA= Bisphenol-glycidyl methacrylate; Bis-GA= Bisphenolglycidyl acrylate; UDMA= urethane dimethacrylate; TEGDMA= triethylene glycol dimethacrylate).

\begin{tabular}{|c|c|c|c|c|}
\hline $\begin{array}{l}\text { Restorative Material and } \\
\text { Batch Number }\end{array}$ & Type & Composition & $\begin{array}{c}\text { Filler } \\
\text { Volume } \\
\% \\
\end{array}$ & $\begin{array}{c}\text { Average Filler } \\
\text { Particle Size } \\
(\mu \mathrm{m})\end{array}$ \\
\hline $\begin{array}{l}\text { Tetric Flow } \\
\text { Ivoclar/Vivadent, } \\
\text { Schaan, Liechtenstein } \\
\text { \# J01757 }\end{array}$ & $\begin{array}{l}\text { Flowable resin } \\
\text { composite }\end{array}$ & $\begin{array}{c}\text { Bis-GMA, UDMA, TEG- } \\
\text { DMA }\end{array}$ & 39.7 & $0.04-3.0$ \\
\hline $\begin{array}{l}\text { Venus } \\
\text { Heraeus Kulzer, } \\
\text { Dormagen, Germany } \\
\text { \# } 010101\end{array}$ & $\begin{array}{l}\text { Hybrid resin } \\
\text { composite }\end{array}$ & Bis-GMA, TEGDMA & 61 & $0.04-0.7$ \\
\hline $\begin{array}{l}\text { Grandio } \\
\text { Voco, Cuxhaven, } \\
\text { Germany } \\
\text { \# } 441042\end{array}$ & $\begin{array}{c}\text { Nanohybrid } \\
\text { resin composite }\end{array}$ & $\begin{array}{c}\text { Bis-GMA, dimethacrylate, } \\
\text { UDMA, TEGDMA }\end{array}$ & 65.6 & $\begin{array}{c}\text { Glass } \\
\text { ceramic(microfiller) } \\
1 \mu \mathrm{m}, \text { SiO2(nanofiller), } \\
20-60 \mathrm{~nm}\end{array}$ \\
\hline $\begin{array}{l}\text { Dyract Extra } \\
\text { Dentsply Caulk, } \\
\text { Milford, DE, USA } \\
\text { \# } 066001434\end{array}$ & $\begin{array}{l}\text { Polyacid-modified } \\
\text { composite resin }\end{array}$ & $\begin{array}{l}\text { UDMA, carboxilic acid } \\
\text { modified dimethacrylate } \\
\text { resin, TEGDMA, BHT, } \\
\text { Strontium- alimino-sodi- } \\
\text { um-fluoro silicate glass, } \\
\text { stronsium fluoride }\end{array}$ & 50 & $\begin{array}{c}0.8 \mu \mathrm{m} \text { inorganic } \\
\text { strontium } \\
\text { fluoride glass } \\
\text { particles }\end{array}$ \\
\hline
\end{tabular}

\section{Measurement of gloss}

Gloss measurements, expressed in gloss units (GU) were performed using a small-area glossmeter (Nova-Curve, Rhopoint Instrumentation, East Sussex, UK), with a square measurement area of $2 \times 2 \mathrm{~mm}$ and 600 geometry. Environment influence was eliminated using a custom-made $10-\mathrm{mm}$ thick black polytetrafluoroethylene mold with the specimen size hole in its center, which has been placed on the top of the specimens during measurements. Three measurements were performed for each specimen.

\section{Measurement of surface hardness}

Microhardness measurements were performed using a Vicker's indentor attached to a microhardness tester (Microhardness Testers HMV-2, Shimadzu Corporation, Kyota, Japan). The indentation load was $100 \mathrm{~g}$ with a 10 seconds dwell time. Three indentations were taken from each specimen that were equally spaced over a circle and not closer than $1 \mathrm{~mm}$ adjacent indentations or the margin of the specimen. The average hardness was calculated for each specimen. 


\section{Statistical analysis}

Means and standard deviations were calculated for surface roughness, gloss and surface hardness. Data were analyzed by Kruskal-Wallis test for surface roughness and hardness. Data for gloss was analyzed by one-way ANOVA and Tukey test. All statistical analysis was conducted at a significance level of $P<.05$.

\section{RESULTS}

The mean Ra values for the four restorative materials at baseline, after immediate finishing/ polishing and delayed finishing/polishing are displayed in Table 2. For all materials, the smoothest surfaces were obtained under Mylar strip (control). There was no statistical difference in surface roughness values of immediate and delayed finished/polished Dyract Extra samples ( $P>$.05). While immediately finished/polished Venus and Grandio samples showed significantly higher roughness values than delayed polishing, immediately finishing/polishing caused smoother surface in Tetric Flow samples $(P<.05)$.

The highest gloss values were recorded under Mylar strip for all materials (Table 3). Delayed fin- ishing/polishing resulted in a significantly higher gloss compared to immediate finishing/polishing in Venus samples $(\mathrm{P}<.05)$. No difference in gloss measurements was observed between delayed or immediate finishing/polishing for the rest of all materials evaluated ( $P>$.05).

Table 4 presents Vickers hardness values of the baseline, immediate and delayed finished/ polished specimens. The lowest hardness values were recorded for all restorative materials under Mylar strip. The highest hardness values were reached when finishing/polishing was delayed $(P<.05)$

\section{DISCUSSION}

The concern about the possible detrimental effects of immediate finishing/polishing procedures on restorative materials has inspired this study. In the present study, finishing and polishing were completed immediately after curing of the restorative materials, because this is a common method in most clinical situations. It has been stated that finishing can be performed immediately after a light-cured resin composite material that has been polymerized, or 5 minutes after the initial harden-

Table 2. Means and standard deviations of surface roughness (Ra, $\mu \mathrm{m})$ for each restorative material.

\begin{tabular}{lccc}
\hline Restorative materials & Mylar & Immediate Finishing/Polishing & Delayed Finishing/Polishing \\
\hline Tetric Flow & $0.013(0.01)$ & $0.140(0.02)$ & $0.195(0.05)$ \\
Venus & $0.022(0.006)$ & $0.144(0.012)$ & $0.127(0.014)$ \\
Grandio & $0.032(0.011)$ & $0.440(0.306)$ & $0.345(0.052)$. \\
Dyract Extra & $0.050(0.006)$ & $0.167(0.015)^{*}$ & $0.179(0.046)^{*}$ \\
\hline
\end{tabular}

* indicates no statistically significant difference within each row $(\mathrm{P}>$.05).

Table 3. Average gloss values (GU) and standard deviations for each restorative material.

\begin{tabular}{lccc}
\hline Restorative materials & Mylar & Immediate Finishing/Polishing & Delayed Finishing/Polishing \\
\hline Tetric Flow & $85.40(10.78)^{\mathrm{a}}$ & $23.88(5.53)^{\mathrm{b}}$ & $28.05(12.10)^{\mathrm{b}}$ \\
Venus & $82.26(6.53)^{\mathrm{a}}$ & $26.46(6.79)^{\mathrm{c}}$ & $33.7(8.14)^{\mathrm{d}}$ \\
Grandio & $82.54(8.18)^{\mathrm{a}}$ & $8.32(0.61)^{\mathrm{e}}$ & $11.73(2.76)^{\mathrm{e}}$ \\
Dyract Extra & $82.40(6.41)^{\mathrm{a}}$ & $15.53(4.04)^{\mathrm{f}}$ & $20.96(11.21)^{\mathrm{f}}$ \\
\hline
\end{tabular}

Within material groups, same superscript letters indicates no statistically significant difference ( $P>05)$.

Table 4. Mean surface hardness and standard deviations for each restorative material.

\begin{tabular}{lccc}
\hline Restorative materials & Mylar & Immediate Finishing/Polishing & Delayed Finishing/Polishing \\
\hline Tetric Flow & $36.50(2.32)^{\mathrm{a}}$ & $46.66(5.07)^{\mathrm{b}}$ & $51.36(4.10)^{\mathrm{c}}$ \\
Venus & $54.90(2.3)^{\mathrm{d}}$ & $65.39(6.1)^{\mathrm{e}}$ & $84.4(11.2)^{\mathrm{f}}$ \\
Grandio & $89.35(11.6)^{\mathrm{g}}$ & $252.78(13.3)^{\mathrm{h}}$ & $280.85(11.0)^{\mathrm{i}}$ \\
Dyract Extra & $46.03(2.7)^{\mathrm{j}}$ & $61.81(2.3)^{\mathrm{k}}$ & $72.07(4.1)^{\mathrm{l}}$ \\
\hline
\end{tabular}

Within material groups, different superscript letters indicates statistically significant difference $(\mathrm{P}<.05)$. 
ing of a self-cured material..11,26 On the other hand, several studies have concluded that microleakage is reduced if polishing of the margins is delayed because of the hydroscopic expansion of the material that reduces the contraction gaps..$^{19,27}$

The surface roughness of a restoration is important for patient's comfort, esthetics, plaque retention and staining. ${ }^{4-6}$ The size and composition of the filler particles of the restoratives determine the material's ability to be finished and polished, thus the smoothness of the restoration. ${ }^{28,29}$ As expected, the smoothest surface was obtained under Mylar strip. During finishing/polishing, the matrix supporting inorganic filler particles might wear away leaving irregularities projecting from the surface. This study showed that immediately finishing/polishing significantly increased the roughness of Venus and Grandio samples but not of Tetric Flow samples. This phenomenon can be explained by the difference in filler content per volume of Tetric Flow resin composite. It might also be partially contributed to the lower degree of polymerization and viscosity of the UDMA monomer in the Tetric Flow material. ${ }^{30}$ The different finishing/polishing times had no effect on the roughness of the polyacid modified resin composite tested compared to the resin composites investigated. A possible explanation for this finding may be the difference in the filler content and matrix composition of the different materials.

The critical threshold surface roughness for bacterial adhesion is $0.2 \mu \mathrm{m} .{ }^{4}$ Only Grandio samples showed surface roughness values greater than $0.2 \mu \mathrm{m}$ after immediate finishing/polishing. After delayed finishing/polishing, Grandio specimens' roughness values were above this critical threshold. This finding was unexpected since Grandio is a nanohybrid composite that contains silicium dioxide particles of 20-50 nm. However, this material also contains $1 \mu \mathrm{m}$ glass ceramic particles that might have been left protruding from the surface after the finishing and polishing procedures. Jung et $\mathrm{al}^{23}$ evaluated the surface texture of four nanohybrid and one hybrid composite after finishing, and found that except for one nanocomposite, all materials were smoother than the hybrid composite tested. In another study evaluating the effect of different polishing systems on the surface roughness and the gloss of various resin composites, the microfill (Durafill), nanofill (Filtek
Supreme), and microhybrid (Esthet-X) resin composites showed smoother and glossier surfaces than the minifill hybrids (Z100 and Z250) tested. ${ }^{9}$ Silikas et $\mathrm{al}^{31}$ compared the surface properties of microhybrid and nanohybrid composites and found no difference in surface roughness of these materials. However, the system used for finishing and polishing also should be taken into account. The types of finishing polishing systems and abrasives might have influenced the roughness and gloss of the materials. On the other hand, we only tested one nano hybrid resin composite. This result could not be extrapolated to all nanohybrid composites. Moreover, many studies concluded that the effectiveness of polishing systems is material dependent. ${ }^{32,33}$ Our aim was to investigate the effect of finishing/polishing time on different restorative materials, not to compare the different polishing methods.

Yap et $a^{34}$ compared the effects of immediate and delayed finishing/polishing procedures on the surface roughness and hardness of toothcoloured restoratives. Contrary to our findings, they reported that delayed finishing/polishing of polyacid-modified composite resins resulted in a smoother surface. They attributed this result to the maturity of the restorative material at the time of finishing/polishing. They also reported that the surface roughness of resin composites was generally not influenced by the finishing/polishing time.

In the present study, we found that delayed finishing/polishing significantly increased the hardness of the tested materials. Our results are also corroborated by another investigation which also proved that delayed finishing/polishing of resin composites generally resulted in a surface of similar or even harder than that obtained with immediate finishing/polishing. ${ }^{34}$ On the other hand, Venturini et al ${ }^{25}$ reported that immediate polishing did not produce a negative influence on the surface roughness, hardness and microleakage of a microfilled (Filtek A110) and a hybrid (Filtek Z250) resin composite compared to delayed polishing. In a recent study, contrary to our findings, the specimens with delayed polishing showed lower hardness results compared to specimens that were polished immediately. ${ }^{35}$ The authors attributed this result to the loss of surface properties after polymerization using a delayed polishing proce- 
dures. They also recommended immediate polishing since this procedure reduces the number of clinical sessions and the wellness of the patients.

It might be expected that smoother surfaces would demonstrate higher gloss values. Lu et $\mathrm{al}^{5}$ stated that the gloss was directly influenced by the surface roughness. On the other hand, Lee et $\mathrm{al}^{36}$ found that the gloss was not only influenced by the surface roughness but also by other factors such as the difference in refractive indices of the resin matrix and the fillers. In the present study, similar to the roughness findings, the highest gloss was obtained under Mylar strip polymerized samples. Although, except for Dyract Extra, finishing/polishing time has changed the roughness of the tested materials, significant differences in gloss values were only observed in Venus samples. Therefore, it might be concluded that the composition of the material rather than the roughness might have an effect on the gloss. Heintze et $\mathrm{al}^{37}$ also stated that the gloss was material dependent.

Mechanical profilometers that provide limited two-dimensional informations are generally employed to measure surface roughness for in vitro investigations. ${ }^{910,18,21,22}$ The main disadvantage of a mechanical profilometer is that the stylus can not detect irregularities that are smaller than its own diameter. In the present study, a 3-D laser surface profilometer was chosen to evaluate the surface roughness, which provides non-contact, rapid, quantitative surface measurements, thus there is no deterioration of the sample. ${ }^{38}$ Additionally, the 3-D laser profilometer uses a beam of light that sweeps the sample surface detecting even angstrom level variations more precisely. ${ }^{38}$

\section{CONCLUSIONS}

Under the limitations of this in vitro study, it might be concluded that:

- For all the restorative materials tested, the smoothest surfaces and highest gloss values were obtained under a Mylar strip and without any finishing/polishing procedure.

- The effect of delayed finishing/polishing on the surface roughness and the gloss of the resin composites tested was material dependent.

- The surface hardness of the resin composites tested increased when finishing and polishing procedures were delayed.

\section{REFERENCES}

1. Anusavice KJ, Antonson SA. Finishing and Polishing Materials in Philip's Science of Dental Materials $11^{\text {th }}$ ed. Philadephia WB Saunders Co., 2003, p. 352-353.

2. Morgan M. Finishing and polishing of direct posterior resin restorations. Prac Proced Aesth Dent 2004;6:211-217.

3. Setcos JC, Tarim B, Suzuki S. Surface finish produced on resin composites by new polishing systems. Quintessence Int 1999;30:169-173.

4. Bollen CM, Lambrechts $P$, Quirynen M. Comparison of surface roughness of oral hard materials to the threshold surface roughness for bacterial plaque retention: A review of the literature. Dent Mater 1997;13:258-269.

5. Lu H, Roeder LB, Lei L, Powers JM. Effect of surface roughness on stain resistance of dental resin composites. J Esthet Restor Dent 2005;17:102-108.

6. Reis A, Giannini M, Lovadino J, Ambrosano G. Effects of various finishing systems on the surface roughness and staining susceptibility of packable composite resins. Dent Mater 2003;19:12-18.

7. Lai YL, Lin YC, Chang CS, Lee SY. Effects of sonic and ultrasonic scaling on the surface roughness of tooth-colored restorative materials for cervical lesions. Oper Dent 2007;32:273-278.

8. O'Brien WJ, Johnston WM, Fanian F, Lambert S. The surface roughness and gloss of composites. J Dent Res 1984;63:685-688.

9. Da Costa J, Ferracane J, Paravina RD, Mazur RF, Roeder L. The effect of different polishing systems on surface roughness and gloss of various resin composites. J Esthet Restor Dent 2007; 19:214-226.

10. Paravina RD, Roeder L, Lu H, Vogel K, Powers JM. Effect of finishing and polishing procedures on surface roughness, gloss and color of resin-based composites. Am J Dent 2004;17:262-266.

11. Craig RG, Ward ML. Restorative Dental Materials $10^{\text {th }}$ ed, Mosby, St. Louis, USA 1997.

12. Rueggeberg FA, Craig RG. Correlation of parameters used to estimate monomer conversion in a light-cured composite. J Dent Res 1988;67:932-937.

13. O'Brien WJ. Physical Properties in Dental Materials and Their Selection. Illinois, Quintessence Publishing Co., $4^{\text {th }}$ ed., 2008, p. 18.

14. Anusavice KJ. Physical Properties of Dental Materials in Philip's Science of Dental Materials $10^{\text {th }}$ ed. Philadephia Saunders, 2003, p. 43.

15. Ferracane JL, Mitchem JC, Condon JR, Todd R. Wear and marginal breakdown of composites with various degrees of cure. J Dent Res 1997;76:1508-1516. 
16. Stanford WB, Fan PL, Wozniak WT, Stanford JW. Effect of finishing on color and gloss of composites with different fillers. J Am Dent Assoc 1985;110:211-213.

17. Inokoshi S, Burrow MF, Kataumi M, Yamada T, Takatsu T. Opacity and color changes of tooth-colored restorative materials. Oper Dent 1996;21:73-80.

18. Turkun LS, Turkun M. The effect of one-step polishing system on the surface roughness of three esthetic resin composite materials. Oper Dent 2004;29:203-211.

19. Irie M, Suzuki K. Effects of delayed polishing on gap formation of cervical restorations Oper Dent 2002;27:59-65.

20. Lopes GC, Franke M, Maia HP. Effect of finishing time and techniques on marginal sealing ability of two composite restorative materials. J Prosthet Dent 2002;88:32-36.

21. Özgünaltay G, Yazici AR, Görücü J. Effect of finishing and polishing procedures on the surface roughness of new tooth-colored restoratives. J Oral Rehabil 2003;30:218-224.

22. Baseren M. Surface roughness of nanofill and nanohybrid composite resin and ormocer-based tooth-colored restorative materials after several finishing and polishing procedures. J Biomater Appl 2004;19:121-133

23. Jung $M$, Sehr K, Klimek J. Surface texture of four nanofilled and one hybrid composite after finishing. Oper Dent 2007;32:45-52.

24. Chung SM, Yap AUJ. Effects of surface finish on indentation modulus and hardness of dental composite restoratives. Dent Mater 2005;21:1008-1016.

25. Venturini D, Cenci MS, Demarco FF, Camacho GB, Powers JM. Effect of polishing techniques and time on surface roughness, hardness and microleakage of resin composite restorations. Oper Dent 2006;31:11-17.

26. Roberson TM, Heymann HO, Swift EJ. Sturdevant's Art and Science of Operative Dentistry 4th edition. St. Louis: Mosby, 2000: 581 .

27. Hansen EK, Asmussen E. Effect of postponed polishing on marginal adaptation of resin used with dentin-bonding agent. Scand J Dent Res 1988;96:260-264.

28. Jung M, Voit S, Klimek J. Surface geometry of three packable and one hybrid composite after finishing. Oper Dent 2003;28:53-59.

29. Roeder LB, Tate WH, Powers JM. Effect of finishing and polishing procedures on the surface roughness of packable composites. Oper Dent 2000;25:534-543.

30. Gonçalves L, Filho JD, Guimarães JG, Poskus LT, Silva EM. Solubility, salivary sorption and degree of conversion of dimethacrylate-based polymeric matrixes. J Biomed Mater Res B Appl Biomater 2008;85:320-325.

31. Silikas N, Kavvadia K, Eliades G, Watts D. Surface characterization of modern resin composites: A multitechnique approach. Am J Dent 2005;18:95-100.
32. Uçtașli MB, Arisu HD, Omürlü H, Eligüzeloḡlu E, Ozcan $S$, Ergun $G$. The effect of different finishing and polishing systems on the surface roughness of different composite restorative materials. J Contemp Dent Pract 2007;8:89-96.

33. Scheibe KG, Almeida KG, Medeiros IS, Costa JF, Alves CM. Effect of different polishing systems on the surface roughness of microhybrid composites. J Appl Oral Sci 2009;17:2126.

34. Yap AU, Sau CW, Lye KW. Effects of finishing/polishing time on surface characteristics of tooth-coloured restoratives. J Oral Rehabil 1998;25:456-461.

35. Cenci MS, Venturini D, Pereira-Cenci T, Piva E, Demarco FF. The effect of polishing techniques and time on the surface characteristics and sealing ability of resin composite restorations after one-year storage. Oper Dent 2008;33:169-176.

36. Lee YK, Lu H, Oguri M, Powers JM. Changes in gloss after simulated generalized wear of composite resins. J Prosthet Dent 2005;94:370-376.

37. Heintze SD, Forjanic M, Rousson V. Surface roughness and gloss of dental materials as a function of force and polishing time in vitro. Dent Mater 2006;22:146-165.

38. Joniot SB, Gregoire GL, Auther AM, Roques YM. Threedimensional optical profilometry analysis of surface states obtained after finishing sequences for three composite resins. Oper Dent 2000;25:311-315. 